\title{
AC 2007-1880: DIVERSITY PROGRAMS AND NUCLEAR ENGINEERING EDUCATION: OUTREACH, RETENTION, AND ENGAGEMENT
}

\section{Lisa Marshall, North Carolina State University}

In Fall 2001, Marshall became the Director of Outreach Programs for the Department of Nuclear Engineering at North Carolina State University. Her research interests lie in enrolment management and engineering education. She is a 'geography of science' doctoral student at the University of North Carolina-Chapel Hill. Before joining NC State University, she worked in enrolment management for several years at Carleton University in Ottawa, Canada.

\section{Mohamed Bourham, North Carolina State University}

Bourham joined the Department of Nuclear Engineering at North Carolina State University in 1987. He is presently the Interim Department Head. As full professor, his research interests include plasma-matter interactions, from interaction with solids to liquids to energetic combustible materials to fabrics and microorganisms. He also is an associate faculty in the Department of Biomedical Engineering with research focusing on medical imaging. 


\title{
Diversity Programs and Nuclear Engineering Education: Outreach, Retention, and Engagement
}

\author{
Mohamed Bourham and Lisa Marshall \\ Department of Nuclear Engineering \\ at North Carolina State University
}

\begin{abstract}
Diversity programs are paramount to nuclear engineering education. It is a process that must begin with pre-engineering programs and become an integral part of the outreach, retention, and engagement mandate of nuclear engineering programs. How does a nuclear engineering program engage in this initiative? Who are the stakeholders, and what roles do they play? How does an industry develop strategies to broaden perception of nuclear science and technology? North Carolina State's Nuclear Engineering program has developed partnerships - on- and off-campus - to increase participation and subsequently affect the number of diverse students graduating and embarking on a nuclear engineering career. Strategies for implementation will be the focus of this paper.
\end{abstract}

Keywords

Nuclear engineering; K12 outreach; diversity programs; women in engineering; minorities in engineering; undergraduate program

Introduction

Past issues of American Society of Engineering Education's Prism and the American Nuclear Society's Nuclear News highlight a concern about diversity within engineering and nuclear engineering. ${ }^{1}$ Referring to the Report of the Congressional Commission on the Advancement of Women and Minorities in Science, Engineering and Technology Development, there is supporting evidence of a troubling trend: low diversity numbers in engineering and nuclear engineering. ${ }^{2}$ The number of Hispanic, Black, and Asian nuclear engineers are below overall engineering figures, and there is low representation of women entering the discipline. A multi-layered approach to improving these numbers is needed from an overall societal well-being perspective. 
Table 1: Total of All Engineers - 2000 Census $^{3}$

\begin{tabular}{|l|l|l|l|l|l|l|l||}
\hline \multicolumn{2}{|c|}{} & Engineers & Caucasian & \multicolumn{1}{|l|}{ Hispanic } & Black & Asian & Other \\
\hline Total & $\begin{array}{l}3,277,360 \\
(100 \%)\end{array}$ & $\begin{array}{l}2,548,315 \\
(77.8 \%)\end{array}$ & $\begin{array}{l}123,883 \\
(3.38 \%)\end{array}$ & $\begin{array}{l}141,000 \\
(4.3 \%)\end{array}$ & $\begin{array}{l}402,770 \\
(12.3 \%)\end{array}$ & $\begin{array}{l}11,042 \\
(0.3 \%)\end{array}$ \\
\hline \multirow{2}{*}{ Male } & $\begin{array}{l}2,723,091 \\
(83.1 \%)\end{array}$ & $\begin{array}{l}2,161,860 \\
(84.8 \%)\end{array}$ & $\begin{array}{l}100,530 \\
((81.2 \%)\end{array}$ & $\begin{array}{l}97,875 \\
(69.4 \%)\end{array}$ & $\begin{array}{l}312,525 \\
(77.6 \%)\end{array}$ & $\begin{array}{l}8,678 \\
(78.6 \%)\end{array}$ \\
\hline \multirow{2}{*}{ Female } & $\begin{array}{l}554,211 \\
(16.9 \%)\end{array}$ & $\begin{array}{l}386,455 \\
(15.2 \%)\end{array}$ & $\begin{array}{l}23,353 \\
(18.8 \%)\end{array}$ & $\begin{array}{l}43,125 \\
(30.6 \%)\end{array}$ & $\begin{array}{l}90,245 \\
(22.4 \%)\end{array}$ & $\begin{array}{l}2,364 \\
(21.4 \%)\end{array}$ \\
\hline
\end{tabular}

Table 2: Total of Nuclear Engineers - 2000 Census $^{3}$

\begin{tabular}{|c||l|l|l|l|l|l||}
\hline & Engineers & Caucasian & Hispanic & Black & Asian & Other \\
\hline \hline Total & $\begin{array}{l}8,540 \\
(100 \%)\end{array}$ & $\begin{array}{l}7,515 \\
(88.0 \%)\end{array}$ & $\begin{array}{l}179 \\
(2.1 \%)\end{array}$ & $\begin{array}{l}200 \\
(2.3 \%)\end{array}$ & $\begin{array}{l}540 \\
(6.3 \%)\end{array}$ & $\begin{array}{l}8 \\
(0.1 \%)\end{array}$ \\
\hline Male & $\begin{array}{l}7,808 \\
(91.4 \%)\end{array}$ & $\begin{array}{l}6,975 \\
(92.8 \%)\end{array}$ & $\begin{array}{l}135 \\
(75.4 \%)\end{array}$ & $\begin{array}{l}120 \\
(60.0 \%)\end{array}$ & $\begin{array}{l}490 \\
(90.7 \%)\end{array}$ & $\begin{array}{l}4 \\
(50 \%)\end{array}$ \\
\hline Female & $\begin{array}{l}718 \\
(8.4 \%)\end{array}$ & $\begin{array}{l}540 \\
(7.2 \%)\end{array}$ & $\begin{array}{l}44 \\
(24.6 \%)\end{array}$ & $\begin{array}{l}80 \\
(40.0 \%)\end{array}$ & $\begin{array}{l}50 \\
(9.3 \%)\end{array}$ & $\begin{array}{l}\text { (50\%) } \\
(50)\end{array}$ \\
\hline
\end{tabular}

Diversity brings to the table differing approaches to problem solving. A heightened awareness of nuclear engineering principles by a larger portion of the population benefits all and this must be stressed. Universities and their partners are in a unique position to systematically influence the next generations of nuclear engineers, and it is to this task that this paper will focus. We will highlight proven practices that are changing the composition of classes, and will eventually change the work environment. It is a process that is urgently needed and relies on relationship building as much as it relies on technical education. The next points will deal with the cradle to career paths that engage and subsequently groom a diverse set of students for the nuclear engineering profession.

\section{Cradle to Career Path - Outreach}

Research shows that students make their decision to opt out of science and math courses by grade seven or eight. "Identifying effective ways to increase and sustain college-going among Latinos [and other underrepresented groups] begins in the pre-college years." It is extremely important that students understand the value of nuclear engineering prior to that moment. Equally important to the point of engagement is the message. In 2006 the WGBH Educational Foundation for the Extraordinary Women Engineers Project found that in thinking about future careers, young girls want to make a difference, work with people, have job flexibility and earn good money - results echoed in the Department of Energy's National Marketing Project of university aged students. The desire does not change, as they get older; as such, nuclear engineering must accentuate this message in age appropriate ways. 
Learning happens outside the classroom as much as it does within; therefore another task at hand is to engage students in many locations. For example, engagements through after-school programs, church groups, boy scouts and girl guides, can provide teachable moments that are not constrained, as is classroom activity. Underrepresented students are found in these organizations, but are likely to be in higher numbers outside currently serviced geographical areas. For instance within North Carolina, outreach programs are primarily within Wake County (where North Carolina State University is located) and surrounding counties. Larger portions of Black and Hispanic populations can be found in counties outside this area.

As with the student population, the population of influencers is diverse. There needs to be engagement with them in the learning and decision making process. Educators, guidance counselors, and parents need to appreciate the benefits of nuclear engineering. In their surroundings as much as on campus should be the setting. Where can you find this diverse group of influencers? At North Carolina State University we have sought them out through pre-service learning in education departments, through Counselors of Color subcommittees of national, regional, and local professional organizations, and through North Carolinas Department of Public Instruction (plus similar governing bodies for private, religious and independent schools). For example, SACAC has an annual Counselors of Color Workshop that we provide information and offer workshops. Parent Teachers' Associations are another entry point to students and their influencers, and engaging diversity through this organization assists as well.

\section{Cradle to Career - Recruitment}

Partnership with university admissions is one logical entry point to recruitment. Most Admissions Offices will have targeted outreach to underrepresented groups. There will be annual programs, for example, the African American or the Native American Visitation Days. At North Carolina State University, the nuclear engineering program attends these exploratory days and follows up with interested individuals in our more detailed nuclear engineering outreach program. Students are then given an opportunity to engage with fellow students, ideally from their own ethnic group, in this discipline specific program. During general recruitment and engineering recruitment programs, particularly Women in Science and Engineering Visitation Days, nuclear engineering is represented. The department's program is two-fold - engage with the students at their location and also on-campus. In-class presentations and, more specifically, traditional direct marketing coupled with telecounseling provide an opportunity to share information not only with the student but also with educators and parents. A follow-up activity has students visit campus, either as a class, a sub-group (for example, female students who are interested in science and engineering), or individually to shadow a class or two and tour the facilities. Student ambassadors are very helpful in this process, bringing a student-to-student perspective to the experience. Once again, matching ethnicity and/or gender assists in this endeavor.

There are other recruitment methods that have been proven to work best in most ethnically underrepresented populations. Some suggestions from Guerrero's Targeting Diversity article include, 
- "Church groups, minority political interest groups, community development agencies, tribal councils, minority professional organizations, minority chamber of commerce, community centers, sports organizations, or minority alumni chapters — should be tapped.

- Jargon-free information programs developed to explain admissions, the college experience, the time commitment their children will have to make, and the importance of a college degree will ease [parents] minds.

- When speaking with parents, recruiters should recognize that the content of a conversation may be less important than the rapport, feeling of trust, and comfort level that need to be established before business can be discussed.

- Role models are extremely effective in getting students to identify with an institution. Using minority students in presentations and having people of color as members of faculty and staff demonstrate an [department's] commitment to diversity and help create a relevant environment for the student.

- Phone calls or personal contact from other students, faculty, and staff are more effective than mailings when working with minorities."5

As much as students and parents are the focus of recruitment, educators must not be forgotten. Science teachers' workshops are useful in this regard. North Carolina State has teamed with the North Carolina Health Physics Society and Progress Energy's Shearon Harris Nuclear Plant to provide workshops in varying locations. We will be launching the Harnessed the Atom program in conjunction with the Department of Energy. This program provides educators with teaching material, equipment and know-how so that they may bring it back into their classroom. Teachers to be chosen will represent not only the geographic composition of the state but also the ethnicity.

\section{Cradle to Career - Retention}

Interesting students and have them apply and get accepted to the nuclear engineering program does not guarantee completion and entrance into field. Key retention activities happen inside and outside of the classroom. Professor, staff and/or peer mentorship assists students in professional development. Tapping into the Minorities in Engineering and the Women in Science and Engineering Program assists the process as well. Students interact with another segment of their peer group. First year is a common engineering year, so through the Introduction to Engineering and Problem Solving course, in particular its freshman research projects, students are engaged with the department. Teams work on a Cherenkov radiation project. Un-matriculated nuclear engineering students are engaged with the department early on, and have resulted in an improved number of diverse students continuing on in the field.

Financial assistance is imperative for many female and underrepresented students. As such, access through the college level and through professional organizations such as the American Nuclear Society (in particular the Nuclear Engineering Education for the Disadvantaged program) to diversity scholarships assists with retention. Closely related to financial assistance are experiential opportunities, be they in the form of internships or cooperative education. 
A future initiative of the department is to have alumni peer mentorship that incorporates diversity pairing. Underrepresented alumni have remarked upon their desire to have such a resource in place when they were school.

\section{Closing Words}

North Carolina State's Nuclear Engineering program is beginning to see the benefits of its targeted approach to outreach, recruitment, and retention. In addition to increasing enrollment numbers overall, there is an increase in the number of incoming female and underrepresented ethnic group students. With a concerted effort to diversify the faculty and expand ethnic specific partnerships, with such organizations as Society of Women Engineers, National Society of Black Engineers, Professional Society of Hispanic Engineers, and the American Indian Science and Engineering Society enrollment levels will continue to increase.

Biographical Information

MOHAMED BOURHAM

Bourham joined the Department of Nuclear Engineering at North Carolina State University in 1987. He is presently the Undergraduate Administrator. As full professor, his research interests include plasma-matter interactions, from interaction with solids to liquids to energetic combustible materials to fabrics and microorganisms. He also is an associate faculty in the Department of Biomedical Engineering with research focusing on medical imaging.

\section{LISA MARSHALL}

In Fall 2001, Marshall became the Director of Outreach Programs for the Department of Nuclear Engineering at North Carolina State University. Her research interests lie in enrolment management and engineering education. She is a 'geography of science' doctoral student at the University of North Carolina-Chapel Hill. Before joining NC State University, she worked in enrolment management for several years at Carleton University in Ottawa, Canada. 
Bibliography

${ }^{1}$ Grose, Thomas K. "Trouble on the Horizon" in Prism, volume 16(2) October 2006

${ }^{1}$ Foulke, Larry. "Diversity in Nuclear-Issues, Initiatives, and Improvements" in Nuclear News, volume 48 (9) August 2005

${ }^{2}$ Commission of the Advancement of Women and Minorities in Science, Engineering and Technology

Development, Report of the Congressional Commission on the Advancement of Women and Minorities in Science, Engineering and Technology Development, September 2000. www.nsf.gov/od/cawmset/

${ }^{3}$ Census 2000 Special Equal Employment (EEO) Tabulation. www.census.gov/hhes/www/eeoindex.html

${ }^{4}$ Venegas, Kristan and Tierney, William. Latino Peer Groups in College Preparation Programs in College and University Journal, volume 81(1) Summer 2005 p. 11

${ }^{5}$ Guerrero, Diana. Targeting Diversity in Handbook for the College Admissions Profession edited by Swann, Claire and Stanley Henderson. Westport, CT: Greenwood Press, 1998 p. 179-80 